\title{
Genetics of male-sterility in gynodioecious Cortaderia (Gramineae)
}

\author{
H. E. Connor* and \\ D. Charlesworth*
}

\author{
* Centre for Resource Management, University of \\ Canterbury, Christchurch, New Zealand. \\ $\uparrow$ Department of Ecology and Evolution, University of \\ Chicago, Chicago, Illinois 60637 , U.S.A.
}

Male-sterility, the only character essential to gynodioecism in Cortaderia is under recessive genic control, the double recessive at any locus producing the syndrome in $C$. selloana. There is evidence that alleles at up to three loci may occur in $C$. selloana giving rise to ratios such as $3 \mathrm{H}: 13 \mathrm{~F}$ and $3 \mathrm{H}: 5 \mathrm{~F}$ in families from the pollination of females by hermaphrodites. No solution is offered to account for the segregation ratios from cross- and self-pollination in $C$. richardii, but control there is genic and probably recessive.

\section{INTRODUCTION}

Gynodioecism is an allogamous system where the male-steriles, females, and hermaphrodite plants of a population interbreed. The genetics of malesterility in gynodioecious species has not been easily or often solved. Early interpretations were of control by nuclear genes (Lewis and Crowe, 1956; Ross, 1969; Connor, 1965b) but nuclear gene control has been more firmly supplanted by nuclear-cytoplasmic explanations (Kheyr-Pour, 1980; Charlesworth, 1981; Van Damme, 1983; Kesseli and Jain, 1984; Couvet et al., 1986; Sun, 1987). Such a conclusion was predicted by Simmonds (1971).

For studies of gynodioecism the deficiency lies in genetic solutions to actual problems and not in the need for theoretical models. Genetic data are especially lacking for wild plants although the genetics of male-sterility are well understood for several species of cultivated plants. We report results derived from several generations of plants grown at Botany Division, DSIR Lincoln, Canterbury, New Zealand, over a 25 year period.

Two attempts have already been made at interpreting the genetics of control of male-sterility in Cortaderia richardii, a New Zealand member of Section Bifida; a single locus with the double recessive as male-sterile was first favoured (Connor, 1965b), and later (Connor, 1973) the two locus model of Lewis and Crowe (1956) was supported because some subsequent results had produced ratios incompletely accommodated by a single gene. Here we offer no solution for $C$. richardii but present the data interpreted as far as is possible, just as Kesseli and Jain (1984) did for Limnanthes douglasii. For C. selloana, a South American member of Section Cortaderia, a solution based on at least two, and probably three, complementary loci with recessive sterility alleles is proposed.

The morphology and development of the flowers of the two sex-forms is described elsewhere as is the frequency of the phenotypes (Connor, 1963, 1965a, 1973). Male-sterility in Section Bifida is expressed after PMC formation but much earlier in Section Cortaderia where staminodes alone develop. The form of the androecium in female plants of Section Cortaderia is dominant over that of Section Bifida (Connor, 1973).

From seed-set to flowering takes 3-4 years for New Zealand species, but one year is mostly sufficient for $C$. selloana.

Most species of Cortaderia are caespitose with intravaginal branching, almost $3 \mathrm{~m}$ tall at flowering, and with a canopy of leaves $2 \mathrm{~m}$ wide or more. The margins of the laminae are armed with sharp, antrorse prickle teeth which cut both the body and clothing-whence the generic name.

\section{TAXA STUDIED}

Ten species were in cultivation in the uniform conditions of the Botany Division Gardens, Lin- 
coln, Canterbury, New Zealand. Most experiments were conducted on C. richardii (Endl.) Zotov (Section Bifida) and C. selloana (Schult. \& Schult. f.) Asch. \& Graeb (Section Cortaderia). Isolated inflorescences of female plants were pollinated by hand; self-pollination was effected in isolation bags. About 25,000 plants were grown over the years; family numbers are used throughout and the number of an individual plant in a family follows, thus G1616-34. Traceable lineages for families are in tables under "Parents".

\section{RESULTS}

\section{Section Cortaderia}

Cortaderia selloana, endemic to Argentina, Brazil and Uruguay but widely naturalized in several parts of the world and usually misinterpreted as dioecious, was investigated. The species is selfincompatible. The two sex-forms are of approximately equal frequency in New Zealand populations (Connor 1965a); a very preliminary assessment of the genetic system was attempted in Connor (1973).

\section{Originating families}

Seed collected from four female plants and one hermaphrodite in sample D at Glenafton, Kopuku, northern Waikato where the population composition was 0.474 hermaphrodites $(H)$ and 0.526 females (F) (Connor, 1965a) gave the families on which all studies were conducted. There were 100 plants in five families (table 1).

Table 1 Sex of progeny in families of $C$. selloana from openpollination of field female and hermaphrodite plants

\begin{tabular}{llrr}
\hline Family & Sex of parent & H & F \\
\hline G5043 & F & 7 & 7 \\
G5044 & F & 12 & 4 \\
G5045 & F & 8 & 6 \\
G5046 & F & 7 & 9 \\
G5047 & H & 22 & 18 \\
\hline
\end{tabular}

The families from open-pollinated female plants were always conspicuously more vigorous than the family from the hermaphrodite and flowered a year before it. The contribution made to the whole population by progenies from hermaphrodites is estimated at $<5$ per cent of that made by obligately cross-pollinated female plants (Connor, 1973).

\section{Controlled cross-pollination}

The results obtained from experimental cross-pollinations are compatible with a model in which at least two, and possibly three, complementary loci with sterility alleles act to produce male steriles with genotypes such as $\mathrm{m}_{1} \mathrm{~m}_{1}, \mathrm{~m}_{2}+$ or $\mathrm{m}_{1} \mathrm{~m}_{1}, \mathrm{~m}_{2}+$ $\mathrm{m}_{3} \mathrm{~m}_{3}$.

At the outset it should be emphasized that several other models cannot be fitted to the results, for example: dominant male-sterility fails because some hermaphrodites yield females in their families; the two locus epistatic Origanum model does not fit because the female frequencies observed here greatly exceed the expectations it generates; and cytoplasmic inheritance is inapplicable because families from females segregate both sex-forms. There is a fuller discussion below.

It should be further emphasized that the model offered emerges, of necessity, from an a posteriori interpretation of data, as in other exploratory genetic work.

Since the originating families were produced by natural pollination, more than a single pollen donor would probably have been involved, and thus the ratios in these families are not very informative, but the interpretation of the model must fit the family backgrounds. In the one family obtained from the selfing of an hermaphrodite, G7075, the origin is clearly more assured.

$S_{1}$ Family G7075. A set of crosses was designed to find out how many genotypes of hermaphrodites occurred in a family derived by selfing an hermaphrodite (G6437-15). Self-incompatibility usually characterises $C$. selloana and this one family was achieved among 35 attempts at selfing. The $S_{1}$ family consisted of $12 \mathrm{H}$ and $3 \mathrm{~F}$, all showing significant inbreeding depression. Such a family is consistent with $3: 1$ or $9: 7$ ratios so it is likely that the parent plant was a heterozygote for one or two recessive sterility alleles. The parent plant and all twelve hermaphrodite progeny plants were tested by crossing to female G5044-7 (table 2). The cross with the parent, G6437-15, gave a segregating family $(107 \mathrm{H}, 148 \mathrm{~F})$ and a ratio consistent with $3: 5$, but not with $1: 1$, suggesting that G6437-15 was heterozygous at two loci, which will be referred to as 1 and 2, and that G5044-7F had the genotype $\mathrm{m}_{1} \mathrm{~m}_{1}, \mathrm{~m}_{2}+$ for loci 1 and 2. Three of the G7075 hermaphrodites yielded only hermaphrodite progeny, so these must have been,++++ . Out of 12 hermaphrodites tested, one would expect 1.33 to be of this genotype in a family produced from selfing the double heterozygote suggested above. The other nine hermaphrodites produced segregat- 
Table 2 Sex of progeny in $C$. selloana of families derived from crossing G5044-7F to all hermaphrodites in $S_{1}$ family G7075. Note that the genotypes are shown for only loci 1 and 2

\begin{tabular}{|c|c|c|c|c|c|}
\hline Parents & $\mathrm{H}$ & $\mathrm{F}$ & $\begin{array}{l}\text { Freq. } \\
\text { females }\end{array}$ & $\begin{array}{l}\chi^{2} \text { for } \\
\text { expected ratio }\end{array}$ & $\begin{array}{l}\text { Interpretation } \\
\text { of genotypes }\end{array}$ \\
\hline \multicolumn{6}{|c|}{ Families that fit $1: 1$ ratios } \\
\hline $\begin{array}{r}\text { G5044-7F } \times \text { G7075-6 } \\
-8 \\
-10 \\
-14\end{array}$ & $\begin{array}{r}118 \\
119 \\
235 \\
8\end{array}$ & $\begin{array}{r}135 \\
126 \\
243 \\
7\end{array}$ & $\begin{array}{l}0.534 \\
0.514 \\
0.508 \\
0.467\end{array}$ & $\begin{array}{l}1 \cdot 14 \\
0 \cdot 20 \\
0 \cdot 13 \\
0 \cdot 07\end{array}$ & $\begin{array}{l}\mathrm{m}_{1} \mathrm{~m}_{1}, \mathrm{~m}_{2}+\times \mathrm{m}_{1}+,++ \\
\mathrm{m}_{1} \mathrm{~m}_{1}, \mathrm{~m}_{2}+\times \mathrm{m}_{1}+,++ \\
\mathrm{m}_{1} \mathrm{~m}_{3}, \mathrm{~m}_{2}+\times \mathrm{m}_{1}+,++ \\
\mathrm{m}_{1} \mathrm{~m}_{1}, \mathrm{~m}_{2}+\times \mathrm{m}_{1}+,++\end{array}$ \\
\hline \multicolumn{6}{|c|}{ Families that fit $3: 5$ ratios } \\
\hline $\begin{array}{r}\text { G5044-7F } \times \text { G7075-1 } \\
-5 \\
-11\end{array}$ & $\begin{array}{l}157 \\
103 \\
105\end{array}$ & $\begin{array}{l}350 \\
149 \\
144\end{array}$ & $\begin{array}{l}0 \cdot 690 \\
0 \cdot 591 \\
0 \cdot 578\end{array}$ & $\begin{array}{l}2 \cdot 16 \\
1 \cdot 22 \\
2 \cdot 32\end{array}$ & $\begin{array}{l}\mathrm{m}_{1} \mathrm{~m}_{1}, \mathrm{~m}_{2}+\times \mathrm{m}_{1}+, \mathrm{m}_{2}+ \\
\mathrm{m}_{1} \mathrm{~m}_{1}, \mathrm{~m}_{2}+\times \mathrm{m}_{1}+, \mathrm{m}_{2}+ \\
\mathrm{m}_{1} \mathrm{~m}_{1}, \mathrm{~m}_{2}+\times \mathrm{m}_{1}+, \mathrm{m}_{2}+\end{array}$ \\
\hline \multicolumn{6}{|c|}{ Families that do not fit any simple ratio } \\
\hline $\begin{array}{r}\mathrm{G} 5044-7 \mathrm{~F} \times \mathrm{G} 7075-4 \\
-13\end{array}$ & $\begin{array}{l}224 \\
212\end{array}$ & $\begin{array}{l}280 \\
262\end{array}$ & $\begin{array}{l}0 \cdot 556 \\
0 \cdot 553\end{array}$ & & \\
\hline \multicolumn{6}{|l|}{ Families with $1: 0$ ratios } \\
\hline $\begin{array}{r}\text { G5044-7F } \times \text { G7075-7 } \\
-9 \\
-12\end{array}$ & $\begin{array}{l}250 \\
250 \\
249\end{array}$ & $\begin{array}{l}0 \\
0 \\
0\end{array}$ & & & $\begin{array}{l}\mathrm{m}_{1} \mathrm{~m}_{1}, \mathrm{~m}_{2}+x++,++ \\
\mathrm{m}_{1} \mathrm{~m}_{1}, \mathrm{~m}_{2}+x++,++ \\
\mathrm{m}_{1} \mathrm{~m}_{1}, \mathrm{~m}_{2}+x++,++\end{array}$ \\
\hline
\end{tabular}

ing families, and table 2 shows the interpretations of the genotypes at loci 1 and 2 . Four of the twelve families fit $1: 1$ ratios compared with $2 \cdot 7 \mathrm{~m}_{1}+$, ++ expected; the smallest of these families also fits a $3: 5$ ratio $\left(\chi^{2}=1 \cdot 60\right)$, so the observed number in this class is either three or four. Three or four families fit a ratio of $3: 5$ (or 0.625 females) compared with an expected number of 5.33 when 12 plants are tested. No family gave $3: 1$, though one would expect the same number of hermaphrodites $\left(++, \mathrm{m}_{2}+\right)$ producing this ratio as those producing $1: 1$. It is not clear whether this distribution of types of families differs significantly from the expected numbers in the different classes of hermaphrodites, because the expected numbers are small so that a $\chi^{2}$ test cannot be used, but the agreement seems fairly good.

A difficulty for the model is that two families (from hermaphrodites 4 and 13) gave female frequencies of about $0 \cdot 55-0 \cdot 56$, which with the large families grown differs significantly from 0.5 or from 0.625 , and these cannot be explained on the basis of the genotype given in table 2 . However, a female plant from family G7075 was crossed with G7075-13-one of the segregating hermaphrodites that gave a 0.55 ratio-and that progeny consisted of $98 \mathrm{H}$ and $152 \mathrm{~F}$. This is consistent with $3: 5\left(\chi^{2}=\right.$ $0 \cdot 31$ ), which suggests that G7075-13 was indeed a double heterozygote, despite the low female frequency it gave when crossed to G5044-7.

Family G5047. This family from open-pollination of a wild hermaphrodite gave an approximately
1:1 ratio (table 1 ). Twelve hermaphrodites of 22 in the family were tested by cross-pollination onto two females of different families. No G5047 female was tested.

Eight different hermaphrodites pollinated G5043-1F. At least four kinds of families resulted (table 3 ). The progenies sired by hermaphrodites G5047-5, -15 and -31 gave approximately $1: 1$ ratios, those of G5047-11 and -40 produced significantly more than 0.5 females while those of G5047-24 produced at least 0.75 females; G504730 and -39 gave hermaphrodites only. These results in segregating families cannot be interpreted with fewer than three loci with recessive sterility alleles, and seem to indicate complementary action of the loci concerned, although the fit to a ratio of $3: 5$ is poor for the family with G5047-40 as pollen donor. Suggested genotypes for each parent are in table 3 .

Other results using two female plants from family G5044 crossed to G5047 hermaphrodites, five of which were the same as those used in the crosses shown in table 3 , were in general agreement with the hypothesis given above. Five families contained hermaphrodites only and the G5047 parents must have been ++ at all sterility loci, while five families segregated. These results are given in detail in table 4 together with suggested genotypes. A very high female frequency was produced by hermaphrodite G5047-24, the same plant that produced a high frequency of females when crossed to G5043-1F; as before, it was deduced to be a triple heterozygote. The same genotype as before 
Table 3 Sex of progeny in C. selloana of families descended from G5043-1F pollinated by hermaphrodites of G5047

\begin{tabular}{|c|c|c|c|c|c|}
\hline Parents & $\mathrm{H}$ & F & $\begin{array}{l}\text { Freq. } \\
\text { females }\end{array}$ & $\begin{array}{l}\chi^{2} \text { for } \\
\text { expected ratio }\end{array}$ & $\begin{array}{l}\text { Interpretation } \\
\text { of genotypes }\end{array}$ \\
\hline \multicolumn{6}{|c|}{ Families that fit $1: 1$ ratios } \\
\hline G5043-1F $\times$ G5047-5 & 176 & 162 & 0.479 & $0 \cdot 58$ & \multirow[t]{3}{*}{$\begin{array}{l}\mathrm{m}_{1} \mathrm{~m}_{1}, \mathrm{~m}_{2}+, \mathrm{m}_{3} \mathrm{~m}_{3} \times \\
\mathrm{m}_{1}+,++,++\end{array}$} \\
\hline$-15^{*}$ & 22 & 28 & 0.560 & 0.72 & \\
\hline-31 & 27 & 21 & $0 \cdot 438$ & 0.75 & \\
\hline \multicolumn{6}{|c|}{ Families with possible $3: 5$ ratios } \\
\hline G5043-1F $\times$ G5047-11* & 116 & 183 & $0 \cdot 612$ & $0 \cdot 22$ & \multirow{2}{*}{$\begin{array}{l}\mathrm{m}_{1} \mathrm{~m}_{1}, \mathrm{~m}_{2}+, \mathrm{m}_{3} \mathrm{~m}_{3} \times \\
\mathrm{m}_{1}+, \mathrm{m}_{2}+,++\end{array}$} \\
\hline-40 & 224 & 295 & $0 \cdot 569$ & $7 \cdot 09$ & \\
\hline \multicolumn{6}{|l|}{ Families with $3: 13$ ratios } \\
\hline G5043-1F × G5047-24* & 50 & 201 & $0 \cdot 801$ & $0 \cdot 23$ & $\begin{array}{l}\mathrm{m}_{1} \mathrm{~m}_{1}, \mathrm{~m}_{2}+, \mathrm{m}_{3} \mathrm{~m}_{3} \times \\
\mathrm{m}_{1}+, \mathrm{m}_{2}+, \mathrm{m}_{3}+\end{array}$ \\
\hline \multicolumn{6}{|l|}{ Families with $1: 0$ ratios } \\
\hline G5043-1F × G5047-30 & 250 & 0 & & & \multirow{2}{*}{$\begin{array}{c}m_{1} m_{1}, m_{2}+, m_{3} m_{3} \times \\
++,++,++\end{array}$} \\
\hline-39 & 246 & 0 & & & \\
\hline
\end{tabular}

* Open-pollination of these hermaphrodites yielded segregating families, viz. 23H, 18F; 31H, 17F; 24H, 20F; respectively.

was also deduced for plant G5047-15. Plant G504711 must, however, have a different genotype from these two. It gave excess females compared with $1: 1$ (table $4 ; \chi^{2}=10 \cdot 50$ ), and was therefore allocated the genotype $\mathrm{m}_{1}+, \mathrm{m}_{2}+,++$, one which would yield a $3: 5$ ratio with a plant of the genotype assumed for G5044-7.

Three of the same hermaphrodites $(-11,-15$ and -24) as used in the crosses with G5043-1F, and three further G5047 hermaphrodites were open- pollinated. The first three all produced ratios similar to $1: 1$, but with too few females (table 3 ), and all three could be fitted by $9: 7$ ratios, which is quite consistent with the idea that all were heterozygous for two recessive sterility alleles that were also heterozygous in the plants that pollinated them. To make this consistent with the results in table 3 , however, it is probably necessary to assume another locus heterozygous in G5047-15. This is not certain, because these progenies of open-polli-

Table 4 Sex of progeny in C. selloana of families with hermaphrodites of G5047 as pollen donors to two females of G5044

\begin{tabular}{|c|c|c|c|c|c|}
\hline Parents & $\mathrm{H}$ & $\mathrm{F}$ & $\begin{array}{l}\text { Freq. } \\
\text { females }\end{array}$ & $\begin{array}{l}\chi^{2} \text { for } \\
\text { expected ratio }\end{array}$ & $\begin{array}{l}\text { Interpretation } \\
\text { of genotypes }\end{array}$ \\
\hline \multirow[t]{8}{*}{ G5044-7F $\times$ G5047-11 } & 94 & 144 & $0 \cdot 605$ & $0 \cdot 40$ & \multirow{8}{*}{$\begin{array}{l}\mathrm{m}_{1} \mathrm{~m}_{1}, \mathrm{~m}_{2}+, \mathrm{m}_{3} \mathrm{~m}_{3} \times \\
\mathrm{m}_{1}+, \mathrm{m}_{2}+,++ \\
\mathrm{m}_{1} \mathrm{~m}_{1}, \mathrm{~m}_{2}+, \mathrm{m}_{3} \mathrm{~m}_{3} \times \\
\mathrm{m}_{1}+,++,++ \\
\mathrm{m}_{1} \mathrm{~m}_{1}, \mathrm{~m}_{2}+, \mathrm{m}_{3} \mathrm{~m}_{3} \times \\
\mathrm{m}_{1}+, \mathrm{m}_{2}+,++ \\
\mathrm{m}_{1} \mathrm{~m}_{1}, \mathrm{~m}_{2}+, \mathrm{m}_{3} \mathrm{~m}_{3} \times \\
\mathrm{m}_{1}+, \mathrm{m}_{2}+, \mathrm{m}_{3}+ \\
\mathrm{m}_{1} \mathrm{~m}_{1}, \mathrm{~m}_{2}+, \mathrm{m}_{3} \mathrm{~m}_{3} \times \\
++,++,++ \\
\mathrm{m}_{1} \mathrm{~m}_{1}, \mathrm{~m}_{2}+, \mathrm{m}_{3} \mathrm{~m}_{3} \times \\
++,++,++ \\
\mathrm{m}_{1} \mathrm{~m}_{1}, \mathrm{~m}_{2}+, \mathrm{m}_{3} \mathrm{~m}_{3} \times \\
++,++,++ \\
\mathrm{m}_{1} \mathrm{~m}_{1}, \mathrm{~m}_{2}+, \mathrm{m}_{3} \mathrm{~m}_{3} \times \\
++,++,++\end{array}$} \\
\hline & 118 & 129 & $0 \cdot 522$ & $0 \cdot 49$ & \\
\hline & 143 & 266 & $0 \cdot 65$ & $1 \cdot 12$ & \\
\hline & 91 & 403 & 0.816 & $0 \cdot 04$ & \\
\hline & 209 & 0 & & & \\
\hline & 275 & 0 & & & \\
\hline & 138 & 0 & & & \\
\hline & 49 & 0 & & & \\
\hline G5044-6F $\times$ G5047-15 & 69 & 70 & $0 \cdot 504$ & 0.01 & $\begin{array}{l}\mathrm{m}_{1} \mathrm{~m}_{1}, \mathrm{~m}_{2}+, \mathrm{m}_{3} \mathrm{~m}_{3} \times \\
\mathrm{m}_{1}+,++,++\end{array}$ \\
\hline-1 & 210 & 0 & & & $\begin{array}{l}\mathrm{m}_{1} \mathrm{~m}_{1}, \mathrm{~m}_{2}+, \mathrm{m}_{3} \mathrm{~m}_{3} \times \\
++,++,++\end{array}$ \\
\hline
\end{tabular}

* Open-pollination of these hermaphrodites yielded hermaphrodite progenies only, $\mathrm{H}=93,94,47$, respectively. 
nation will probably have come from more than a single pollen donor, so that the ratios might be due to mixtures. The other three hermaphrodites tested all gave exclusively hermaphrodite families (table 4), which suggests that these plants were all ++ at all the sterility loci. This is also possible given the genotypes assumed for the parents of this family.

These interpretations should be also consistent with the $1: 1$ ratio in the originating family G5047, which was produced by intercrossing hermaphrodites. Four hermaphrodite genotypes are identified among the 12 tested $\mathrm{m}_{1}+, \mathrm{m}_{2}+, \mathrm{m}_{3}+(1)$, $\mathrm{m}_{1}+, \mathrm{m}_{2}+,++(3), \mathrm{m}_{1}+,++,++(3),++$, ,$++++(5)$; these could have arisen from interpollination of an hermaphrodite heterozygous at each locus viz $\mathrm{m}_{1}+, \mathrm{m}_{2}+, \mathrm{m}_{3}+$. Minimally, ++ , $\mathrm{m}_{2}+, \mathrm{m}_{3}+$ as a pollen donor would fulfil all requirements, but the frequencies of some genotypes e.g.,,,++++++ would indicate other hermaphrodite pollen parents.

Family G5044. Hermaphrodites G5044-2 and -12 were both used to pollinate their female sib G50447 , whose genotype was deduced above to be $m_{1} m_{1}$, $\mathrm{m}_{2}+$. Both progenies segregated $1: 1$ ratios $(115 \mathrm{H}$, $117 \mathrm{~F} ; 123 \mathrm{H}, 131 \mathrm{~F}$ ) and the suggested genotype for the hermaphrodites is $\mathrm{m}_{1}+,++$.

Hermaphrodite G5044-15 was open-pollinated and three of its female progeny were backcrossed with the parent G5044-15 and also with a different hermaphrodite from the same family, G5044-2. All these crosses yielded large families with $1: 1$ ratios, $(660 \mathrm{H}, 699 \mathrm{~F})$ so it is clear that only one locus is segregating in them.

A similar set of crosses was made using four female progeny from open-pollination of G5044-2. Now, the three plants pollinated by the hermaphrodite G5044-15 again gave 1:1 ratios $(334 \mathrm{H}$, $360 \mathrm{~F}$ ); so did two of those pollinated by G5044-2 $(174 \mathrm{H}, 203 \mathrm{~F})$, but one very small family gave $3 \mathrm{H}$ and $11 \mathrm{~F}$. This latter family fits $1: 3$ or $3: 13$, ratios unattainable on back-crossing to females derived from the parental genotype $\mathrm{m}_{1}+,++$.

The history of family G5044 suggests that if the original female parent of the family was allocated the genotype $\mathrm{m}_{1} \mathrm{~m}_{1},++, \mathrm{m}_{3}+$ and pollen genotypes were minimally $\mathrm{m}_{1} \mathrm{~m}_{2} \mathrm{~m}_{3}, \mathrm{~m}_{1}++$, + $\mathrm{m}_{2}+,+++$ all requirements would be met. All of these genotypes are credible in the pollen cloud of the very large population from which the G5044 parent was drawn.

It should be recorded that among the progeny from open-pollination of G5044-15H one ++ , ++ hermaphrodite was recovered; this is in keeping with expectations.
Families G5043, G5045, G5046. These three families were among the originating material (table 1 ), and yielded some data consistent with the general model.

Female plant G5043-1 was used commonly in controlled pollination (table 3 ). The $1: 1$ ratio of hermaphrodites to females in family G5043 suggests that the male parent(s) was heterozygous for a recessive sterility allele, $\mathrm{m}_{1}$, which was homozygous in the female. An hermaphrodite from family G5043 was crossed to an unrelated female, G50446 , and gave a $1: 1$ ratio $(118 \mathrm{H}, 128 \mathrm{~F})$, which is consistent with the interpretation given above for the cross that produced this family. The suggestion (table 3 ) that female G5043-1 carried other recessive sterility factors, in addition to $\mathrm{m}_{1}$, is not inconsistent with the $1: 1$ ratio in its family, provided that the parental genotypes at the other loci were such that no segregation would occur.

In family G5045, plant-10 provided pollen for crosses to the commonly used females G5044 -6F and $-7 \mathrm{~F}$; the progenies contained $118 \mathrm{H}, 142 \mathrm{~F}$ and $117 \mathrm{H}, 123 \mathrm{~F}$ respectively. These $1: 1$ results are identical to those obtained throughout the crosses reported here; the genotypes, too, are probably identical, stemming from a family of $8 \mathrm{H}$ and $6 \mathrm{~F}$.

A somewhat contradictory and inexplicable result occurred in a directly comparable pair of crosses with hermaphrodite G5046-2 pollinating G5044-6F and $-7 \mathrm{~F}$. The former gave a family of $99 \mathrm{H}$ and $137 \mathrm{~F}$ which would best fit a $7: 9$ ratio; the latter gave a family of $49 \mathrm{H}, 52 \mathrm{~F}$, compatible with a $1: 1$ ratio.

\section{Observations on model}

No evidence of cytoplasmic factors was obtained in these crosses, but this could not have been expected because most crosses involved females as the maternal parents, and reciprocal crosses were not made between hermaphrodite plants. Also, four of the original five seed parent plants in the field were females, and could have had the same cytoplasm, even if there were two or more types in the natural population of origin. It is not unlikely that such differences would be found, if they were looked for, since they seem to be present in so many gynodioecious species (Van Damme, 1983).

It should be mentioned that the data permit us to exclude many other genetic hypotheses. For example, dominant male sterility, with or without a cytoplasmic polymorphism, is ruled out because wholly hermaphrodite families are observed when females are used as the maternal parents. The model of Lewis and Crowe (1956) is also unlikely, 
because it does not yield families with female frequencies above $\frac{1}{2}$, other than wholly female families, and these are not found in C. selloana. It is also unlikely that the data could be explained by a purely cytoplasmic mode of inheritance. This is obvious for a model in which the sterility cytoplasm invariably gives the female phenotype, but it is also clear that we cannot invoke an unstable cytoplasm that allows some hermaphrodites to have female progeny. If that were so, then an hermaphrodite which has female progeny should transmit the same cytoplasm to its hermaphrodite progeny, and they should be incapable of giving large, wholly hermaphrodite families, but these do occur in the data set. Similar reasoning rules out models in which $\mathrm{m}+$ plants show biased segregation in favour of $m$, or where the ++ genotype is inviable. Therefore, despite some minor discrepancies discussed above, it seems likely that the model proposed here is essentially correct for this species.

A model such as that proposed by Van Damme (1983) for Plantago lanceolata, where sterility is produced only when the sterility genotype is present at all of a set of loci, could also possibly fit the data, but there appear to be more difficulties for such a model than for the one proposed. That model fails to explain the families with female frequencies above 0.5 , but less than 0.75 , which have been interpreted above as $3: 5$ ratios. The finding of high female frequencies, such as $1: 3$ ratios when a female is used as maternal parent, could be consistent with this model, if the hermaphrodite genotype were heterozygous for a dominant sterility factor that was heterozygous in the female. This requires that the hermaphrodite should have a cytoplasm on which this factor is not expressed, or else it would be a female. The only candidate for such a genotype of hermaphrodite in the data is G5047-24. If this plant has a dominant sterility factor that is present in the females with which it gave high ratios of females (i.e., G5044-7 and G5043-1), we would expect it to be present in its siblings, but there is no evidence for this factor in the segregating families involving female G5043-1 pollinated by five different siblings of this plant, nor in the seven families of hermaphrodite siblings with G5044-7 as maternal parent. Nevertheless, because G5047 is a product of openpollination, it is possible that such an allele could be present in only one of the plants in this family, so the fact that it is absent from the siblings is not conclusive evidence against such a model. Furthermore, of the two families that had a high female frequency, the family with G5044-7 as female parent is inconsistent with a $1: 3$ ratio, but fits a $3: 13$ ratio which is predicted by the phenotypes

Table 5 Behaviour of hermaphrodites in originating family G1616 of C. richardii

\begin{tabular}{|c|c|c|c|c|c|}
\hline Family & Parents & & $\mathrm{H}$ & $\mathrm{F}$ & $\begin{array}{l}\text { Classification of } \\
\text { hermaphrodites }\end{array}$ \\
\hline \multicolumn{6}{|c|}{ Cross-pollination } \\
\hline G3818 & \multicolumn{2}{|c|}{$\mathrm{G} 1616-34 \mathrm{~F} \times \mathrm{G} 1616-26$} & 11 & 7 & Heterozygous \\
\hline G3819 & $x$ & -12 & 11 & 9 & Heterozygous \\
\hline G3824 & $-32 \mathrm{~F} \times$ & -11 & 3 & 5 & Heterozygous \\
\hline G3816 & $-34 F \times$ & -48 & 19 & 0 & Homozygous \\
\hline G3817 & $x$ & -39 & 20 & 0 & Homozygous \\
\hline G3820 & $\times$ & -6 & 20 & 0 & Homozygous \\
\hline G3821 & $-32 \mathrm{~F} \times$ & -46 & 20 & 0 & Homozygous \\
\hline G3823 & $x$ & -17 & 20 & 0 & Homozygous \\
\hline \multicolumn{6}{|c|}{ Self-pollination } \\
\hline G3826 & \multicolumn{2}{|l|}{ G1616-11 } & 14 & 5 & Heterozygous \\
\hline G3827 & \multicolumn{2}{|l|}{-26} & 7 & 7 & Heterozygous \\
\hline G4318 & \multicolumn{2}{|l|}{-12} & 10 & $0^{*}$ & Heterozygous \\
\hline $\mathrm{G} 4320$ & \multicolumn{2}{|l|}{.33} & 8 & 2 & Heterozygous \\
\hline G3825 & \multicolumn{2}{|l|}{-6} & 20 & 0 & Homozygous \\
\hline G3828 & \multicolumn{2}{|l|}{-39} & 20 & 0 & Homozygous \\
\hline G3829 & \multicolumn{2}{|l|}{-48} & 20 & 0 & Homozygous \\
\hline G4319 & \multicolumn{2}{|l|}{-17} & 6 & 0 & Homozygous \\
\hline \multicolumn{6}{|c|}{ Open-pollination } \\
\hline G3830 & \multicolumn{2}{|l|}{ G1616-25 } & 20 & 0 & Homozygous \\
\hline G3831 & \multicolumn{2}{|l|}{-17} & 20 & 0 & Homozygous \\
\hline G3832 & \multicolumn{2}{|l|}{-6} & 20 & 0 & Homozygous \\
\hline
\end{tabular}

* Classified as heterozygous on the basis of the segregating family from cross-pollination. 
proposed in tables 3 and 4 . On the other hand, it is possible that some genes with complementary action might be involved in this species, even if this is not such an important feature of the genetic basis as it is in Plantago laceolata. For example, it could help to explain the ratios that were found in some families that lie between $1: 1$ and $3: 5$. If the cross involved the genotypes $\mathrm{m}_{1} \mathrm{~m}_{1}, \mathrm{~m}_{2}+$, $\mathrm{m}_{4}+\times \mathrm{m}_{1}+, \mathrm{m}_{2}+, \mathrm{m}_{4}+$, where loci 2 and 4 must both be homozygous for the sterility alleles for the female phenotype to appear, the expected ratio is $17 / 32$ or 0.531 .

The consideration of these models for the inheritance of male sterility permits the conclusion to be made with some certainty that at least three loci with recessive alleles are involved though, not surprisingly, the exact mode of gene interaction cannot be determined. Given the small number of wild plants used as the origin for these breeding tests, it is remarkable that so many genes should have been found.

\section{Section Bifida}

Cortaderia richardii, a South Island, New Zealand endemic, was most extensively investigated. In the wild, populations of $C$. richardii on average comprise $0.625 \mathrm{H}$, and $0.375 \mathrm{~F}$. Other indigenous species were incorporated into interspecific hybrid generations, and the sex-form segregations in these were reported earlier (Connor, 1983).

The original family of $C$. richardii was raised from seed collected from a single plant in the Ashburton Gorge, Mid-Canterbury. Family G1616 consisted of $41 \mathrm{H}$ and $9 \mathrm{~F}$. All families described here are descended from them. The genetic behaviour of hermaphrodite plants was determined from selfing, and from cross-pollination of females.

The behaviour of ten hermaphrodites in the originating family is in table 5; both homozygous and heterozygous genotypes were present.

\section{Self-pollination of Hermaphrodites}

Data from 32 self-pollinations are in table 6; New Zealand species are highly self-fertile.

Fifteen families segregating both sex-forms are consistent with their heterozygous origin; there is no heterogeneity. Ten $F_{2}$ 's would best fit $13: 3$ ratios. Five $S_{1}$ families are not heterogeneous and fit both $13: 3\left(\chi^{2}=2 \cdot 35\right)$ and $3 \mathrm{H}: 1 \mathrm{~F}\left(\chi^{2}=0 \cdot 64\right)$; families were quite small. Four $\mathrm{S}_{2}$ non-segregating families are consistent with their homozygous origin in the single plant G1616-48 (see also table 5), as are $13 \mathrm{~S}_{1}$.

The single result from selfing $C$. toetoe fits a $3: 1$ ratio.

\section{Cross-pollination of Females}

Data from 35 cross-pollinations are in table 7 . In C. richardii there are 26 families with sex-form segregation; the data are homogeneous $\left(\chi_{25}^{2}=\right.$ $35 \cdot 20)$. The $16 F_{2}$ families are not heterogeneous

Table 6 Sex of progeny in families from self-pollination of hermaphrodites of $C$, richardii and $C$. toetoe

\begin{tabular}{|c|c|c|c|c|}
\hline Family & Parent & $\mathbf{H}$ & $\mathrm{F}$ & $\begin{array}{l}\text { Freq. } \\
\text { females }\end{array}$ \\
\hline \multicolumn{5}{|c|}{$\mathrm{F}_{2}$ C. richardii } \\
\hline G5777 & G3819-3 & 88 & 16 & $0 \cdot 154$ \\
\hline G5778 & -11 & 88 & 19 & 0.178 \\
\hline G5779 & -15 & 90 & 17 & $0 \cdot 159$ \\
\hline G5780 & -16 & 84 & 22 & $0 \cdot 208$ \\
\hline G5781 & G3817-4 & 81 & 19 & $0 \cdot 190$ \\
\hline G5782 & -6 & 92 & 17 & $0 \cdot 156$ \\
\hline G5783 & -15 & 81 & 21 & $0 \cdot 206$ \\
\hline G5784 & -18 & 78 & 22 & 0.220 \\
\hline G6399 & G3824-5 & 68 & 30 & $0 \cdot 306$ \\
\hline G6400 & -6 & 30 & 11 & $0 \cdot 268$ \\
\hline \multicolumn{4}{|l|}{$13: 3 \chi^{2}=0.87$} & \\
\hline \multicolumn{5}{|c|}{$\mathrm{S}_{1}$ C. richardii } \\
\hline G6383 & G3832-2 & 34 & 13 & $0 \cdot 277$ \\
\hline G6387 & -9 & 35 & 11 & $0 \cdot 239$ \\
\hline G6389 & -11 & 34 & 12 & $0 \cdot 261$ \\
\hline G6392 & -14 & 36 & 8 & $0 \cdot 182$ \\
\hline G6395 & -17 & 38 & 8 & $0 \cdot 174$ \\
\hline G6381 & G3832-5 & 43 & 0 & \\
\hline G6382 & -3 & 46 & 0 & \\
\hline G6384 & -1 & 16 & 0 & \\
\hline G6385 & -7 & 46 & 0 & \\
\hline G6386 & -8 & 45 & 0 & \\
\hline G6388 & -10 & 42 & 0 & \\
\hline G6390 & -12 & 40 & 0 & \\
\hline G6391 & -13 & 47 & 0 & \\
\hline G6393 & -15 & 44 & 0 & \\
\hline G6394 & -16 & 46 & 0 & \\
\hline G6396 & -18 & 46 & 0 & \\
\hline G6397 & -19 & 46 & & \\
\hline G6398 & .20 & 6 & 0 & \\
\hline \multicolumn{5}{|c|}{$\mathrm{S}_{2}$ C. richardii } \\
\hline G5785 & G3829-2 & 107 & 0 & \\
\hline G5786 & -10 & 100 & 0 & \\
\hline G5787 & -13 & 102 & 0 & \\
\hline G5788 & -16 & 106 & 0 & \\
\hline \multicolumn{5}{|l|}{$\mathrm{S}_{1}$ C. toetoe } \\
\hline G9687 & G3793-2 & 166 & 51 & 0.235 \\
\hline \multicolumn{5}{|l|}{$3: 1 \chi^{2}=0.26$} \\
\hline
\end{tabular}


Table 7 Sex of progeny in families from cross-pollination of females in C. richardii, and $C$. splendens

\begin{tabular}{|c|c|c|c|c|c|}
\hline Family & \multicolumn{2}{|l|}{ Parents } & $\mathrm{H}$ & $\mathrm{F}$ & $\begin{array}{l}\text { Freq. } \\
\text { females }\end{array}$ \\
\hline \multicolumn{6}{|c|}{$\mathrm{F}_{2}$ C. richardii } \\
\hline \multicolumn{6}{|c|}{ Families fitting $1: 1$ ratios } \\
\hline G8829 & \multicolumn{2}{|c|}{$\mathrm{G} 3819-17 \mathrm{~F} \times \mathrm{G} 3816-15$} & 116 & 93 & $0 \cdot 445$ \\
\hline G8831 & & $\begin{array}{ll}\times & -18\end{array}$ & 67 & 67 & $0 \cdot 500$ \\
\hline G8832 & & $\times \mathrm{G} 3818-14$ & 135 & 115 & $0 \cdot 460$ \\
\hline G8833 & & $\begin{array}{ll}x & -16\end{array}$ & 56 & 61 & $0 \cdot 521$ \\
\hline G8834 & & $\times \mathrm{G} 3819-14$ & 76 & 58 & $0 \cdot 443$ \\
\hline G8835 & & $\begin{array}{ll}\times & -19\end{array}$ & 48 & 57 & 0.543 \\
\hline G8837 & & $\times \quad-6$ & 102 & 87 & $0 \cdot 460$ \\
\hline G8838 & & $\times \mathrm{G} 3816-17$ & 140 & 111 & $0 \cdot 442$ \\
\hline G8840 & G3819-12F & $\times \mathrm{G} 3817-6$ & 132 & 116 & $0 \cdot 468$ \\
\hline G8841 & & $\begin{array}{ll}x & -18\end{array}$ & 250 & 253 & $0 \cdot 502$ \\
\hline G8842 & & $\times \mathrm{G} 3819-6$ & 136 & 108 & $0 \cdot 443$ \\
\hline G8843 & & $\times \mathrm{G} 3820-9$ & 132 & 118 & $0 \cdot 472$ \\
\hline G8844 & & $\times \mathrm{G} 3823-16$ & 135 & 117 & 0.464 \\
\hline \multicolumn{6}{|c|}{ Families fitting $5: 3$ ratios } \\
\hline G8830 & \multicolumn{2}{|c|}{$\mathrm{G} 3819-17 \mathrm{~F} \times \mathrm{G} 3817-4$} & 143 & 107 & 0.428 \\
\hline G8836 & & $\times$ G3823-4 & 151 & 101 & $0 \cdot 401$ \\
\hline G8839 & \multicolumn{2}{|c|}{$\mathrm{G} 3819-12 \mathrm{~F} \times \mathrm{G} 3816-20$} & 147 & 99 & 0.402 \\
\hline \multicolumn{6}{|c|}{$\mathrm{BC}_{1}$ C. richardii } \\
\hline \multicolumn{6}{|c|}{ Families fitting $1: 1$ ratios } \\
\hline G7790 & \multicolumn{2}{|c|}{$\mathrm{G} 3819-2 \mathrm{~F} \times \mathrm{G} 5778-77$} & 68 & 64 & 0.485 \\
\hline G7792 & & $\times \quad-97$ & 74 & 56 & 0.431 \\
\hline G7795 & G3819-9F > & -81 & 109 & 104 & $0 \cdot 488$ \\
\hline G7799 & $\mathrm{G} 3819-12 \mathrm{~F}>$ & -79 & 64 & 80 & $0 \cdot 555$ \\
\hline G7800 & & -82 & 34 & 43 & 0.558 \\
\hline G7802 & & -88 & 64 & 61 & 0.488 \\
\hline G7804 & & -96 & 37 & 40 & 0.520 \\
\hline G7805 & G3819-17F> & -95 & 5 & 5 & $0 \cdot 500$ \\
\hline \multicolumn{6}{|c|}{ Families fitting $5: 3$ ratios } \\
\hline G7791 & \multicolumn{2}{|c|}{$\mathrm{G} 3819-2 \mathrm{~F} \times \mathrm{G} 5778-80$} & 107 & 67 & $0 \cdot 385$ \\
\hline G7801 & $\mathrm{G} 3819-12 \mathrm{~F}$ & $\begin{array}{ll}\times & -86\end{array}$ & 133 & 92 & $0 \cdot 409$ \\
\hline \multicolumn{6}{|c|}{ Families fitting $1: 0$ ratios } \\
\hline G7787 & \multirow{4}{*}{ G3819-2F } & $\times \mathrm{G} 5778-67$ & 202 & 0 & \\
\hline G7788 & & $\begin{array}{ll}\times & -70\end{array}$ & 184 & 0 & \\
\hline G7789 & & -72 & 54 & 0 & \\
\hline G7793 & & -98 & 194 & 0 & \\
\hline G7794 & $\mathrm{G} 3819-5 \mathrm{~F}>$ & -83 & 185 & 0 & \\
\hline G7796 & \multirow{3}{*}{ G3819-9F } & -87 & 103 & 0 & \\
\hline G7797 & & -90 & 75 & 0 & \\
\hline G7798 & & -91 & 7 & 0 & \\
\hline G7803 & \multicolumn{2}{|l|}{ G3819-12F $\times$} & 102 & 0 & \\
\hline \multicolumn{6}{|c|}{$\mathrm{F}_{1} \mathrm{C}$. splendens } \\
\hline 10872 & \multicolumn{2}{|c|}{ G6945-7F $\times$ G6945-5 } & 106 & 125 & $0 \cdot 541$ \\
\hline
\end{tabular}

$\left(\chi_{15}^{2}=17 \cdot 39\right)$ but do not fit simple ratios for the control of male-sterility $\left(1: 1 \chi^{2}=24 \cdot 44 ; 9: 7 \chi^{2}=\right.$ $6 \cdot 82)$. Segregation in all $\mathrm{F}_{2}$ families is consistent with the heterozygous origin of the hermaphrodite parents. The $10 \mathrm{BC}_{1}$ segregating families, which often involved the same female parents as $F_{2}$, are heterogeneous $\left(\chi_{9}^{2}=17 \cdot 66\right)$ and do not fit $1: 1\left(\chi^{2}=\right.$ $5 \cdot 27)$ or $9: 7\left(\chi^{2}=5 \cdot 02\right)$.
Overall in the segregating families, three $F_{2}$ (G8830, G8836, G8839) and two BC, (G7791, G7801) individually best fit $5: 3$ ratios; collectively they do not $\left(\chi^{2}=4 \cdot 830\right)$. The other $21 \mathrm{~F}_{2}$ and $\mathrm{BC}_{1}$ families individually fit $1: 1$, but not collectively $\left(\chi^{2}=7 \cdot 263\right)$.

That hermaphrodite plants in family G5778 behave either homozygously $(n=9)$ or heterozy- 
Table 8 Plant height, and inflorescence number and length in families of $C$. richardii descended from female and hermaphrodite plants of family G3819

\begin{tabular}{llll}
\hline & \multicolumn{2}{l}{ Progenies from } & \\
\cline { 2 - 3 } & \multicolumn{2}{l}{ Open-pollination of } & Self-pollination \\
& of hermaphrodites \\
\cline { 2 - 3 } & Females & Hermaphrodites & \\
\hline Plant height $(\mathrm{m})$ & $2 \cdot 40 \pm 0 \cdot 01^{* *}$ & $2 \cdot 29 \pm 0 \cdot 02$ & $2 \cdot 20 \pm 0 \cdot 01$ \\
No. inflorescences per plant & $97 \pm 1 \cdot 7^{* *}$ & $75 \pm 1 \cdot 6$ & $71 \pm 1 \cdot 6$ \\
Inflorescence length $(\mathrm{cm})$ & $58 \cdot 7 \pm 0 \cdot 37^{* *}$ & $55 \cdot 6 \pm 0 \cdot 41$ & $56 \cdot 8 \pm 0 \cdot 38$ \\
No. in sample & 459 & 480 & 396 \\
\hline
\end{tabular}

** Significantly different $P<0 \cdot 01$.

gously $(n=10)$, is consistent with their origin in the selfing of G3819-11 an hermaphrodite plant of known heterozygous origin (table 5). These $\mathrm{BC}_{1}$ data also indicate the frequency in one segregating family of hermaphrodites generating the three genetic ratios identified, viz: eight with $1: 1$, two with $5: 3$, nine with $1: 0$, but as there is no background against which to test this distribution, a comment on the apparent high frequency of nonsegregating families would be unfounded.

Ratios of $5: 3$ in families from cross-pollination of females, and of $13: 3$ in families from selfing hermaphrodites, influenced Connor's support (1973) of the 2-locus model of Lewis and Crowe (1956). However, in two particulars the C. richardii data depart from that model: no families comprise females only, and no 3:1 ratios occur in families from crosses to females.

A single cross-pollination in C. splendens segregated $1: 1\left(\chi^{2}=1 \cdot 56\right)$.

There is no orthodox nuclear model to fit the selfing or crossing data for endemic New Zealand species. No cytoplasmic or nuclear-cytoplasmic system appears to obtain. Dominant male-sterility is inconsistent with the results. One approximation could be based on recessive male-sterility alleles, perhaps two, and a causally unknown post-zygotic reduction in the frequency of females. As such, this nuclear gene approximation is an exception to the general solutions described by Charlesworth (1981), but in line with what we report here for $C$. selloana. The details of the system in New Zealand species are so incomplete that an extended discussion on this point is both unwarranted and unrewarding.

\section{Fitness}

Estimates of the relative fitness of generations from open-pollination of females and hermaphrodites and from selfing were reported earlier (Connor,
$1965 b)$. From much larger plantings somewhat better estimates of fitness are available (table 8).

Families from open-pollinated female plants are taller and significantly more productive than families from open-pollinated hermaphrodites. Families from self-pollinated hermaphrodites are not significantly different from those of open-pollinated origin. The results are interpreted as a 1.5times advantage to families from cross-pollinated females, and in agreeing with experiments reported on earlier, confirm the conclusion (Connor, 1973) that self-pollination is a predominant state in $C$. richardii hermaphrodites. Inbreeding depression at 30 per cent is not substantial evidence that selection pressures should favour maintenance of outcrossing females in the system.

Among the progenies from cross-pollinated females there were no significant differences in height, or number and size of inflorescences per plant associated with sex-form. Female plants of themselves appear to possess no special vigour, the significant features lying in larger seeds and in better germination of seeds from female plants (Connor, 1965b) which, it is assumed, must contribute to the measured heterosis.

\section{CONCLUSIONS}

Perhaps predictably, no uniform system controlling male-sterility operates in Cortaderia spp. of Section Cortaderia and Section Bifida; the differences in morphological expression of malesterility and its timing are themselves developmentally significant. But the differences are not such that the alleles in species of each section are unable to interact in intersectional hybrids and allow the expression of male-sterility.

For $C$. richardii no model for control of malesterility is proposed, but it is not under dominant 
gene control, or cytoplasmic, or nuclear-cytoplasmic control.

The solution offered here for male-sterility control in C. selloana based on up to three complementary loci with recessive alleles, extends the number and kind of control systems for male-sterility in flowering plants. The results suggest, too, that in the original population probably many other loci are segregating for recessive sterility factors. This agreement with the results of Van Damme for dicotyledonous Plantago lanceolata is therefore very striking. It is as yet unclear why gynodioecious populations have so many sterility, or restorer, loci polymorphic.

Acknowledgements Mr I. C. Brown, formerly of Botany Division, DSIR, grew and cared for all the plants described here; A. H. McRae and the late A. W. Purdie also of Botany Division, assisted in performing cross-and self-pollinations, and in sexing the progenies. All three are warmly thanked.

\section{REFERENCES}

C.HARLESWORTH, D. 1981. A further study of the problem of the maintenance of females in gynodioecious species. Heredity, 46, 27-39.
CONNOR. H. E. 1963. Breeding systems in New Zealand grasses. IV. Gynodioecism in Cortaderia. N.Z.J. Botany, 1, 258-264.

CONNOR, H. E. $1965 a$. Breeding systems in New Zealand grasses. V. Naturalised species of Cortaderia. N.Z.J. Botany, 3, 17-23.

CONNOR, H. E. 1965b. Breeding systems in New Zealand grasses. VI. Control of gynodioecism in Cortaderia richardii. N.Z.J. Botany, 3, 233-242.

CONNOR. H. E. 1973. Breeding systems in Cortaderia (Gramineae). Evolution, 27, 663-678.

CONNOR. H. E. 1983. Cortaderia: interspecific hybrids and the breeding system. Heredity, 51, 395-403.

COUVET, D., BONNEMAISON, F. AND GOUYON. P-H. 1986. The maintenance of females among hermaphrodites: the importance of nuclear-cytoplasmic interactions. Heredity, $57,325-330$.

KESSELI, R. AND JAIN, S. K. 1984. An ecological genetic study of gynodioecy in Limnanthes douglasii (Limnanthaceae). Amer. J. Botany, 71, 775-786.

KHEYR-POUR, A. 1980. Nucleo-cytoplasmic polymorphism for male-sterility in Origanum vulgare L. J. Heredity, 71, 253260.

LEWIS, D. AND CROWE, K. 1956. The genetics and evolution of gynodioecy. Evolution, 10, 115-125.

ROSS, M. D. 1969. Digenic inheritance of male-sterility in Plantago lanceolata. Canad. J. Genet. Cytol. 11, 739-744.

SIMMONDS, N. W. 1971. The breeding system of Chenopodium quinoa-1. Male sterility. Heredity, 27, 73-82.

SuN, M. 1987. Genetics of gynodioecy in Hawaiian Bidens (Asteraceae). Heredity, 59, 327-336.

VAN DAMME. J. M. M. 1983. Gynodioecy in Plantago lanceolata L. II. Inheritance of three male-sterility types. Heredity, $50,253-273$. 